\title{
Pengaruh Struktur Kalimat Bahasa Jawa terhadap Penggunaan Bahasa Indonesia Siswa Kelas V SD Negeri 171 Purwosari Kecamatan Tomoni Timur Kabupaten Luwu Timur
}

\author{
Harsia \\ Universitas Cokroaminoto Palopo \\ harsia1945@gmail.com
}

\begin{abstract}
Abstrak
Penelitian ini bertujuan mengungkap (i) pengaruh struktur kalimat bahasa Jawa terhadap kemampuan analisis bahasa Indonesia sebagai bahasa kedua siswa kelas V SD Negeri 171 Purwosari di Kecamatan Tomoni Timur Kabupaten Luwu Timur, (ii) kemampuan menulis jenis kalimat siswa kelas V SD Negeri 171 Purwosari di Kecamatan Tomoni Timur Kabupaten Luwu Timur, (iii) implikasi pemerolehan bahasa Jawa sebagai bahasa pertama dan pemerolehan bahasa Indonesia sebagai bahasa kedua terhadap pengajaran bahasa Indonesia siswa kelas V SD Negeri 171 Purwosari di Kecamatan Tomoni Timur Kabupaten Luwu Timur. Jenis penelitian ini termasuk eksploratori dengan menggunakan pendekatan analitik, sintetik dan mactching. Analitik, sintetik, dan mactching. Kemudian menyelidiki dan menarik kesimpulan dari satuan-satuan yang terpisah itu secara holistik (selinger, 1989). Di antara satuan-satuan bahasa yang diteliti dalam penelitian ini adalah satuan sintaksis berupa kalimat siswa SD kelas V. Hasil penelitian menunjukkan bahwa penggunaan struktur kalimat bahasa pertama yang sesuai maupun yang tidak sesuai dengan struktur kalimat bahasa Indonesia sebagai bahasa kedua. Jenis kalimat yang digunakan responden dalam karangannya adalah kalimat tanya seperti kata berapa, apa, kapan, kenapa (mengapa), kalimat penyangkalan seperti kata ingkar tidak (semua responden pada umumnya mampu menggunakan kata ingkar tidak), sebagian besar responden menggunakan kalimat majemuk dalam karangan kurang sesuai dengan kaidah bahasa kedua (bahasa Indonesia). Penggunaan kalimat pasif dan aktif dalam karangannya kurang sesuai dengan kaidah bahasa kedua (bahasa Indonesia). Implikasi pemerolehan bahasa pertama (bahasa Jawa) dan pemerolehan bahasa Indonesia sebagai bahasa kedua terhadap pengajaran bahasa Indonesia (mengenai struktur kalimat) di sekolah terjadi kesenjangan di antara bahasa pertama dan bahasa kedua artinya bahwa pengajaran bahasa Indonesia di sekolah dipengaruhi oleh penggunaan bahasa pertama responden, baik dari segi kaidah bahasa pertama maupun dari segi aksen bahasa pertama.
\end{abstract}

Kata kunci: pengaruh, struktur, kalimat, bahasa pertama, bahasa kedua

\section{Pendahuluan}

Di Indonesia terdapat bermacam-macam etnis atau suku bangsa yang terbesar di seluruh pelosok tanah air. Tiap-tiap etnis hampir dapat dikatakan memunyai bahasa daerah sebagai bahasa ibu (Kridalaksana, 2008). Bahasa daerah itu digunakan oleh masyarakat pendukungnya untuk kepentingan komunikasi yang sifatnya intern atau sesama suku (Poedjosoedarmo, 1994:2). Sebagai contoh bahasa Jawa digunakan oleh masyarakat Jawa jika berkomunikasi dengan orang-orang yang berasal dari etnis Jawa. Namun, ada kalanya orang-orang nonetnis Jawa juga menggunakan bahasa Jawa dalam berkomunikasi dalam situasi tertentu (Widada,1994:31).

Bahasa daerah adalah bahasa ibu bagi kebanyakan masyarakat di Indonesia, khususnya masyarakat di Kecamatan Tomoni Timur Kabupaten Luwu Timur sebagai wilayah "Indonesia Mini" yang di dalamnya hidup berdampingan beberapa suku dan 
bahasa daerah yang berbeda seperti bahasa Bugis, Toraja, Jawa, dan bahasa Bali. Namun, perbedaan suku dan bahasa daerah dapat dipersatukan melalui bahasa Indonesia sebagai bahasa kedua bagi mereka (Harsia, 2018:1). Berdasarkan penjelasan Undang-Undang Dasar 1945, Bab XV, Pasal 36 dinyatakan bahwa bahasa yang dipelihara baik-baik oleh masyarakatnya akan dipelihara dan dihormati oleh negara (Pasmidi, 1998:68).

Uraian di atas, memberikan angin segar kepada masyarakat Bugis, Toraja, Jawa, dan Bali yang berdomisili di wilayah transmigrasi, khususnya masyarakat transmigrasi di Kecamatan Tomoni Timur Kabupaten Luwu Timur yang ingin melestarikan bahasa ibu (bahasa daerah). Masyarakat merupakan lembaga pelastarian nilai-nilai tertentu yang menjadi sumber nilai bagi warganya. Bagi masyarakat Bugis, Toraja, Jawa, dan Bali bahasa ibu (bahasa daerah) dan budaya daerah ibarat saudara kembar siam yang tak mudah dilepaspisahkan. Bahasa Bugis, Toraja, Jawa, Bali yang juga merupakan bahasa ibu adalah pemberi warna dan wujud jati diri sejak seseorang dilahirkan (Harsia, 2018:1). Dalam banyak hal warna kedaerahannya bisa dilihat dari bahasanya. Bahasa daerah bukan hanya wahana untuk menelusuri sejarah wilayah pakai suatu bahasa, melainkan bahasa itu sendiri menjadi juru bahasa semua masa lalu (Fishman, 1973). Mudah dipahami kalau masyarakat Bugis, Toraja, Jawa, dan Bali mencintai dan ingin melastarikan bahasanya karena kekayaan dalam bahasa tersebut dapat digunakan untuk menelusuri budaya daerah (Harsia, 2018:1).

Pelestarian suatu bahasa dapat dilaksanakan dengan bermacam-macam cara. Salah satu di antaranya melalui pendidikan secara formal sedini mungkin, yaitu mengajarkan bahasa daerah sejak SD. Dengan pengajaran bahasa daerah yang dimulai sejak SD, juga memberi warna terhadap penggunaan bahasa Indonesia sebagai bahasa kedua bagi siswa.

Agaknya sudah merupakan keyakinan umum bahwa pemerolehan bahasa kedua sangat kuat dipengaruhi oleh bahasa pertama sang pebelajar. Dukungan yang paling jelas terhadap keyakinan ini muncul dari aksen-aksen ' asing' dalam ujaran bahasa kedua sang pebelajar. Misalnya: kalau orang Bali orang Jawa berbahasa Indonesia, maka bahasa Indonesianya beraksen Jawa. Contoh dalam bidang sintaksis yaitu kalimat yang merupakan kalimat bahasa Indonesia untuk pola kalimat B1 (bahasa ibu/pertama): Saya sedang mandi. (B1/Bahasa Jawa: kulO sawək siram).

Berkenaan dengan hal tersebut, penelitian ini membahas "Pengaruh Struktur Kalimat Bahasa Jawa terhadap Penggunaan Bahasa Indonesia Siswa Kelas V SD Negeri 171 Purwosari di Kecamatan Tomoni Timur Kabupaten Luwu Timur". Hal-hal yang mendasari penelitian ini adalah banyaknya siswa kelas V SD Negeri 171 Purwosari di Kecamatan Tomoni Timur Kabupaten Luwu Timur yang belum dapat menggunakan bahasa Indonesia dengan baik dan benar. Salah satu faktor yang memengaruhi hal itu terjadi karena pada umumnya siswa ketika di lingkungan rumahnya berbahasa daerah (bahasa Jawa). Kecamatan Tomoni Timur memang merupakan salah satu wilayah yang ada di Kabupaten Luwu Timur yang penduduknya mayoritas masyarakat transmigrasi, baik transmigrasi umum maupun transmigrasi swakarsa.

Dalam penelitian ini tidak semata-mata bertujuan memperlihatkan hasil pemerolehan berupa imput atau autput yang dinyatakan dengan jumlah atau frekuensi data, melainkan perubahan dalam lintasan proses pemerolehan (bahagian 
dari language processor). Prosesor-bahasa yaitu bagian-bagian dari otak manusia, sistem motorik, persepsi, dan aparat yang sesuai untuk pengolahan bahasa-tidak hanya mampu menghasilkan bahasa dan memahami tetapi juga menyesuaikan produksi bahasa dan pemahaman terhadap materi linguistik tertentu (Klein, 1988:39). Seperti yang diuraikan Klein (1988:6): language processor yakni learner's faculty of producing and comprehending utterance in a ginen context.

Penelitian seperti ini masih jarang dilakukan. Penelitian terdahulu umumnya menggambarkan perkembangan jumlah kosa kata yang dikuasai oleh anak tingkat usia tertentu tidak memperlihatkan strukturnya, frekuensi kemunculannya, serta tempat kemunculannya dalam ujaran (kalimat) (Klein, 1988:66).

Berdasarkan latar belakang di atas, maka dapat dirumuskan masalah penelitian ini. Adapun rumusan masalah tersebut adalah sebagai berikut:

1. Bagaimana pengaruh struktur kalimat bahasa Jawa terhadap kemampuan analisis bahasa Indonesia sebagai bahasa kedua siswa kelas V SD Negeri 171 Purwosari di Kecamatan Tomoni Timur Kabupaten Luwu Timur?

2. Bagaimana kemampuan menulis jenis kalimat siswa kelas V SD Negeri 171 Purwosari di Kecamatan Tumoni Timur Kabupaten Luwu Timur?

3. Bagaimana implikasi pemerolehan bahasa pertama dan pemerolehan bahasa Indonesia sebagai bahasa kedua terhadap pengajaran sintaksis siswa kelas V SD Negeri 171 di Kecamatan Tomoni Timur Kabupaten Luwu Timur?

\section{Tinjauan Pustaka Interferensi dan Intagrasi \\ a. Interferensi}

Interferensi dalam bidang sintaksis, diambil contoh kalimat dalam bahasa Indonesia dari seorang bilingual Jawa-Indonesia dalam berbahasa Indonesia. Bunyi kalimat itu "Di sini took Laris yang mahal sendiri" (diangkat dari Djoko Kentjono, 1982). Kalimat bahasa Indonesia itu berstruktur bahasa Jawa, sebab dalam bahasa Jawa bunyinya adalah "Ning kene took Laris sing larang dhewe". Kata sendiri dalam kalimat bahasa Indonesia itu merupakan terjemahan dari kata Jawa dhewe. Kata dhewe dalam bahasa Jawa, antara lain, memang berarti 'sendiri', seperti terdapat dalam kalimat "Aku dhewe sing took" (Saya sendiri yang datang), dan "Kowe krungu dhewe?" (apakah kamu mendengarnya sendiri). Tetapi kata dhewe yang terdapat di antara kata sing dan adjektif adalah berarti 'paling', seperti sing dhuwur dhewe 'yang paling tinggi', dan sing larang dhewe 'yang paling mahal'. Dengan demikian, dalam bahasa Indonesia baku kalimat tersebut di atas seharusnya berbunyi "Toko Laris adalah took yang paling mahal di sini". Contoh lain, struktur kalimat bahasa Indonesia, "Makanan itu telah dimakan oleh saya" adalah dipengaruhi oleh bahasa Sunda, karena kalimat Sundanya adalah "Makanan the atos dituang ku abdi". Dalam bahasa Indonesia baku susunannya haruslah menjadi, "Makanan itu telah saya makan" (Chaer dan Agustina 2004:123-124)

Penggunaan serpihan kata, frase, dan klausa di dalam kalimat dapat juga dianggap sebagai interferensi pada tingkat kalimat. Perhatikan serpihan-serpihan dari bahasa lain yang terdapat dalam kalimat-kalimat bahasa Indonesia berikut!

- Mereka akan married bulan depan.

- Nah karena saya sudah kadhung apik sama dia, ya saya tanda tangan saja (Nah karena saya sudah benar-benar baik dengan dia, maka saya tanda tangani saja) 
- Yah apa boleh buat, better loat noit (Yah apa boleh buat, lebih baik terlambat daripada tidak sama sekali).

- Pimpinan kelompok itu selalu mengatakan education is necessary for life (Pemimpin kelompok itu selalu mengatakan, bahwa pendidikan adalah perlu dalam kehidupan) (Chaer dan Agustina, 2004:124)

Namun, kalau dilihat dari usaha pengembangan bahasa, interferensi ini merupakan suatu rahmat, sebab dia merupakan suatu mekanisme yang sangat penting untuk memperkaya dan mengembangkan suatu bahasa untuk mencapai taraf sebagai bahasa yang sempurna untuk dapat digunakan dalam segala bidang kegiatan. Malah Hockett (1958) mengatakan bahwa interferensi merupakan satu gejala terbesar, terpenting, dan paling dominan dalam bahasa. Dalam perkembangan bahasa Indonesia di bidang fonologi misalnya kita lihat sebelum berlakunya EYD tahun 1972, bunyi /f/ dari bunyi/x/ yang berasal dari bahasa asing belum diakui berstatus sebagai fonem bahasa Indonesia. Tetapi di dalam EYD telah diakui sebagai fonem karena terdapatnya pasangan-pasangan minimal untuk bunyi-bunyi tersebut, antara lain pada kata-kata kapan X kafan dank has X kas (seperti kita ketahui persyaratan untuk menentukan sebuah bunyi berstatus sebagai sebuah fonem adalah terdapatnya pasangan minimal yang mengandung bunyi tersebut).

Kiranya kontribusi terutama dari interferensi itu adalah dalam bidang kosakata. Bahasa-bahasa yang memunyai latar belakang budaya dan pemakaian yang luas (seperti bahasa Inggris dan bahasa Arab) dank arena itu memunyai kosakata yang secara relatif sangat banyak, akan banyak member kontribusi kosakata kepada bahasa-bahasa yang berkembang dan yang memunyai kontak dengan bahasa tersebut. Dalam proses ini bahasa yang memberi atau memengaruhi itu disebut bahasa sumber atau bahasa donor; dan bahasa yang menerima disebut bahasa penyerap atau bahasa resepien, sedangkan unsur yang diberikan disebut unsur serapan atau inportasi. Dalam sejarah perkembangannya, bahasa Indonesia yang berasal dari bahasa Melayu banyak menyerap unsur-unsur bahasa, baik dari bahasa asing (Arab, Cina, Sansekerta, Belanda, Inggris, dan sebagainya), maupun dari bahasabahasa Nusantara. Semua unsur serapan itu, terutama serapan leksikal, turut membangun khazanah kosakata bahasa Indonesia sehingga bahasa yang digunakan dewasa ini telah dapat memenuhi fungsinya sebagai bahasa modern, yang dapat digunakan untuk pelbagai ranah (domain) dalam kehidupan bangsa Indonesia (Chaer dan Agustina, 2004:126)

Menurut Soewito (1983:59) interferensi dalam bahasa Indonesia dan bahasabahasa Nusantara berlaku bolak-balik, artinya, unsur bahasa daerah bisa memasuki bahasa Indonesia dan bahasa Indonesia banyak memasuki bahasa-bahasa daerah. Tetapi dengan bahasa asing, bahasa Indonesia hanya menjadi penerima dan tidak pernah menjadi pemberi. Lihat bagan dari Soewito (1983) berikut!

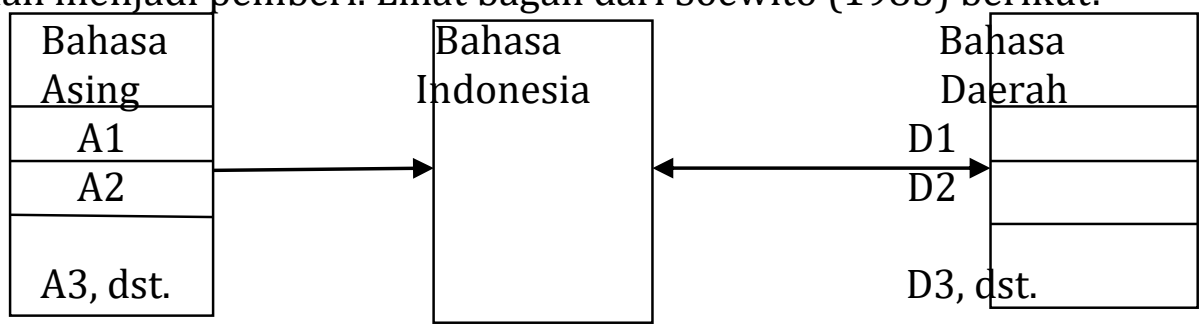

Gambar 1 
Interferensi Asing-Bahasa Indonesia- Bahasa Daerah

Sehubungan dengan adanya bahasa yang "kaya dengan kosakata (seperti bahasa Inggris dan bahasa Arab), dan bahasa yang masih berkembang yang kosakatanya belum banyak. Timbul pertanyaan, apakah hanya bahasa"kaya" yang bisa menjadi donor, dan bahasa "miskin" hanya menjadi resepien, ataukah sebaliknya: bahasa "miskin" juga dapat menjadi donor terhadap bahasa "kaya". Menurut logika, memang hanya bahasa yang kayalah yang memunyai peluang untuk menjadi donor; sedangkan bahasa miskin hanya menjadi resepien, dan tak berpeluang untuk menjadi bahasa donor. Namun, dalam kenyataannya, karena bahasa itu erat kaitannya dengan budaya masyarakat penuturnya, maka dapat dikatakan (tidak sejalan dengan pendapat Soewito) bahwa bahasa miskin pun dapat menjadi donor kosakata kepada bahasa kaya, terutama untuk kosakata yang berkenaan dengan budaya dan alam lingkungan bahasa donor. Dalam kamus Longman Dictionary of Contemporary English (London, 1982, Longman Group Ltd) terdaftar banyak sekali kosakata bahasa Indonesia/Melayu yang sudah lazim digunakan dalam bahasa Inggris, seperti: bamboo, mango, kampong, kapok, karma, orang utan, dan gorilla. Jadi, interferensi leksikal bukanlah ditentukan oleh kaya dan miskin suatu bahasa, melainkan oleh pengaruh budaya masyarakat bahasa yang melekat pada bahasa itu. Oleh karena itu, bagan yang dibuat Soewito (1983) perlu dimodifikasi menjadi:

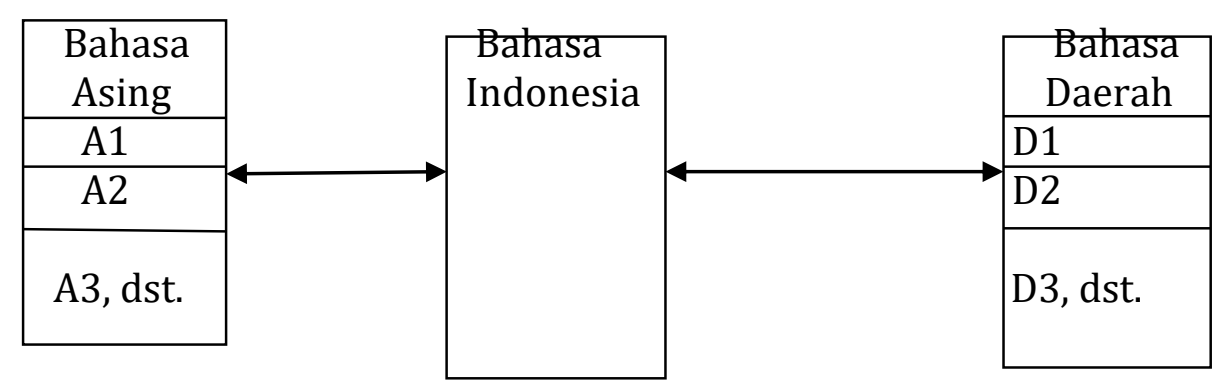

Dengan bagan tersebut tampak bahwa bahasa Indonesia dan bahasa asing saling bertukar unsur leksikal; bahasa Indonesia dan bahasa daerah pun demikian juga.

\section{b. Integrasi}

Meckey (1970) menjelaskan bahwa integrasi adalah unsur-unsur bahasa lain yang digunakan dalam bahasa tertentu dan dianggap sudah menjadi warga bahasa tersebut. Tidak dianggap lagi sebagai unsur pinjaman atau pungutan.

Penerimaan unsur bahasa lain dalam bahasa tertentu sampai menjadi berstatus integrasi memerlukan waktu dan tahap yang relatif panjang. Pada mulanya seorang penutur suatu bahasa menggunakan unsur bahasa lain itu dalam tuturannya sebagai unsur pinjaman karena terasa diperlukan, misalnya, karena dalam B1-nya unsur tersebut belum ada padanannya (atau bisa juga telah ada tetapi dia tidak mengetahuinya). Kalau kemudian unsur asing yang digunakan itu bisa diterima dan digunakannya juga oleh orang lain, maka jadilah unsur tersebut berstatus sebagai unsur yang sudah berintegrasi. Umpamanya, kata Inggris reseaich pada tahun 60-an sampai tahun 70-an digunakan sebagai unsur yang belum berintegrasi. Ucapan dan ejaannya masih menurut bahasa aslinya. Tetapi kemudian ucapan dan ejaannya 
mengalami penyesuaian, sehingga ditulis sebagai riset. Maka, sejak itu kata riset tidak dianggap lagi sebagai unsur pinjaman, melainkan sudah menjadi kosakata bahasa Indonesia, atau kosakata bahasa Inggris yang telah berintegrasi ke dalam bahasa Indonesia.

Proses penerimaan unsur bahasa asing, khususnya unsur kosakata, di dalam bahasa (Indonesia) pada awalnya tampak banyak dilakukan secara audial. Artinya, mula-mula penutur Indonesia mendengar butir-butir leksikal itu dituturkan oleh penutur aslinya, lalu mencoba menggunakannya. Apa yang terdengar oleh teliga, itulah yang diujarkan, lalu dituliskan. Oleh karena itu, kosakata yang diterima secara audial seringkali menampakkan ciri ketidakteraturan bila dibandingkan dengan kosakata aslinya. Perhatikan contoh kosakata bahasa Indonesia berikut, lalu bandingkan dengan bentuk aslinya. Sebelah kiri kosakata bahasa Indonesia dan sebelah kanan bentuk aslinya.

$\begin{array}{ll}\text { klonyo } & \text { - eau de cologne } \\ \text { dongkrak } & \text { - dome kracht } \\ \text { atret } & \text { - achter uit } \\ \text { persekot } & \text { - voorschot } \\ \text { sopir } & \text { - chauffeur } \\ \text { sirsak } & \text { - zuursak } \\ \text { pelopor } & \text { - voorloper }\end{array}$

Pada tahap berikutnya, terutama setelah pemerintah mengeluarkan Pedoman Umum Pembentukan Istilah dan Pedoman Umum Ejaan Bahasa Indonesia Yang Disempurnakan (Lihat dalam Moeliono, 1988) penerimaan dan penyerapan kata asing dilakukan secara visual. Artinya, penyerapan itu dilakukan melalui bentuk tulisan dalam bahasa aslinya, lalu bentuk tulisan itu disesuaikan menurut aturan yang terdapat dalam kedua dokumen kebahasaan di atas. Umpamanya, system menjadi sistem (bukan sistim), phonem menjadi fonem, standart menjadi standar, standardization menjadi standardisasi (bukan standarisasi), hierarchy menjadi hierarki (bukan hirarki) dan repertoire menjadi repertoir (bukan repertoar). Sedangkan unsur serapan yang dalam bahasa aslinya tidak ditulis dalam aksara Latin misalnya aksara Arab dan Sirilik, diserap dengan cara transliterasi atau transkripsi. Dalam hal penyerapan visual ini, patut disimak kasus penyerapan kata Prancis repertoire dan trotoir yang tulisannya (menurut sistem ejaan bahasa Indonesia) tidak sesuai dengan lafalnya. Karena itu, meskipun pedoman umum pembentukan istilah menetapkan harus menjadi repertoire dan trotoir tetapi dalam masyarakat umum kita dapati bentuk repertoar dan trotoar. Ini menunjukkan perkembangan bahasa itu bukannya tidak bisa diatur, melainkan lebih sering bersifat alamiah (Chaer dan Agustina, 2004:129

\section{Penelitian Pemerolehan Bahasa di dalam Kelas}

Sejak tahun 1960-an, sudah banyak penelitian dilakukan orang terhadap proses belajar bahasa dan pengajaran bahasa di dalam kelas. Dalam penelitian tersebut, peneliti pada umumnya mengambil tingkah laku guru atau siswa di kelas, atau mengambil hasil belajar bahasa (learning outcomes) siswa sebagai objek penelitiannya. Beberapa penelitian tersebut meneliti bentuk-bentuk dan banyaknya tugas instruksional, partisipasi guru dan siswa dalam kelas, begitu juga fungsi dan bentuk bahasa yang dipergunakan oleh guru dalam proses belajar mengajar, yang diteliti dengan menggunakan metode kuantitatif (Chaudron, 1990:1). Namun, 
penggunaan kelas yang sengaja "diubah" untuk tujuan penelitian, menurut Van Lier (1988) bukan merupakan ciri yang tepat sebuah penelitian yang mengikuti secara alami dalam kelas. Penelitian yang dibenarkan adalah penelitian yang mengikuti secara alami keseluruhan proses instruksional dan interaksional yang terjadi di dalam kelas. Untuk ini peneliti disarankan memilih metode penelitian kualitatif, khususnya etnografi mikro agar tercatat keseluruhan proses dan produk yang terjadi di dalam kelas. Hasil catatan lapangan beserta refleksi dan interpretasi yang dihasilkan oleh peneliti pada gilirannya, dapat menjadi tumpuan yang amat kuat bagi perumusan teori belajar bahasa kedua dalam kelas (Van Lier, 1988; Chaudron, 1988: Ellis, 1990).

Pada penelitian pertama Dulay dan Burt mencoba membandingkan urutan pemerolehan bahasa kedua (PB2) pada anak-anak yang berasal dari lokasi tempat tinggal berbeda-beda; pada penelitian kedua Dulay dan Burt mencoba membandingkan urutan pemerolehan bahasa kedua (PB2) pada anak-anak yang memiliki bahasa pertama (B1) berbeda; dan pada penelitian ketiga Dulay dan Burt mencoba membandingkan urutan pemerolehan B2 (PB2) pada anak-anak yang memiliki lokasi tempat tinggal dan latar bahasa pertama (B1) berbeda. Penelitian Mulyadi mencoba membandingkan urutan pemerolehan bahasa Indonesia Tulis (BIT) pada siswa-siswa SMP yang memiliki lokasi tempat tinggal berbeda (Saryono, 2010:97).

Dulay dan Burt (1978) meneliti urutan pemerolehan 8 morfem gramatikal bahasa Inggris pada anak-anak berbahasa ibu Spanyol. Anak-anak itu berjumlah 150 orang dan tinggal di tega tempat, yaitu Sacramento (95 anak), San Ysidro (26 anak), dan East Harlem (30 anak). Dengan menggunakan BSM (Bilingual Syantax Measure) yang diperluas, anak-anak dari tiga kelompok tempat tinggal itu dites. Hasil penelitian ini menunjukkan bahwa anak-anak yang bertempat tinggal berbeda itu memperoleh 8 morfem gramatikal yang diteliti dalam urutan mirip atau hampir sama (Saryono, 2010:98).

Mulyadi (1987) mencoba meneliti urutan pemerolehan struktur kalimat bahasa Indonesia tulis pada siswa-siswa SMP berbahasa ibu bahasa Jawa (BJ) yang tinggal di 3 lingkungan tempat tinggal bahasa, yaitu lingkungan desa, pinggiran, dan kota. Sebanyak 12 struktur B1 dijaring dengan menggunakan tes mengarang terbimbing, dalam hal ini tes menerjemahkan wacana bahasa Jawa (BJ) ke dalam wacana BIT (Bahasa Indonesia Tulis). Dengan menggunakan alat analisis Metode Skor Kelompok dan Korelasi Spearman, Mulyadi menemukan bahwa terdapat urutan umum pemerolehan struktur kalimat BIT antara siswa SMP yang tinggal di desa, pinggiran, dan kota. Ditemukan juga bahwa tidak ada perbedaan signifikan urutan pemerolehan 12 struktur kalimat BIT antara siswa SMP yang tinggal di desa, pinggiran, dan kota. Jadi, lingkungan bahasa dan tempat tinggal tidak membedakan urutan pemerolehan 12 struktur kalimat BIT (Saryono, 2010:99).

Olson dan Samaule menemukan bahwa siswa SMP dan SMA belajar lafal lebih baik daripada siswa SD. Asher dan Gracia justru menemukan bahwa ketetapan lafal tidak dapat ditentukan secara biologis, Ervin dan Tripp membuktikan bahwa anakanak yang lebih tua belajar lebih cepat daripada mereka yang berusia muda, antara 4 - 6 tahun. Snow dan Hoefnagale menemukan bahwa orang dewasa maju lebih cepat pada awalnya tetapi pada akhirnya lebih lambat. Chun membuktikan bahwa masingmasing kelompok usia (6-13 tahun, dan 18 -41 tahun) memunyai kelebihan setidak- 
tidaknya satu aspek B2. Dengan temuan-temuan ini berarti hipotesis umur kritis ditolak (Chun, 1980 dalam Saryono, 2010:99).

Bagaimana kaitan umur dengan urutan pemerolehan B2? Beberapa kajian menunjukkan bahwa umur tidak memengaruhi urutan pemerolehan B2. Dulay dan Burt meneliti urutan pemerolehan 11 morfem gramatikal bahasa Inggris pada anakanak berumur 7 - 9 tahun yang berbahasa ibu Cina dan Spanyol. Dengan menggunakan BSM, data diambil. Kemudian dianalisis dengan menggunakan Metode Skor Kelompok, Metode Rata-rata Kelompok dan Indeks Pemerolehan Sintaksis. Hasil analisis menunjukkan bahwa 11 morfem gramatikal bahasa Inggris mengikuti urutan umum atau mirip. Jadi, urutan pemerolehan 11 morfem gramtikal pada anak-anak yang umur dan B1 berbeda relatif sama. Hal ini menunjukkan bahwa anak-anak menguasai suatu struktur secara alamiah dengan urutan umum (Saryono, 2010:100).

Baily, Medden, dan Krashen (1978) meneliti urutan pemerolehan B2 pada orang dewasa. Sebanyak 73 orang dewasa yang berumur 17-55 tahun dijadikan subjek. Mereka berbahasa ibu bahasa Spanyol dan non-Spanyol. Delapan morfem gramatikal dicari urutannya pada mereka. Dengan menggunakan BSM delapan morfem gramatikal itu dijaring. Hasil analisis menunjukkan bahwa pemelajar dewasa menggunakan strategi pemerolehan yang sama dengan anak-anak, dan kemampuan pemelajar dewasa sama dengan anak-anak dalam hal pemerolehan morfem yang sama.

Fatman menguji lebih lanjut hubungan umur dengan pemerolehan B2. Dia mengadakan penelitian dua kali. Pertama, dia menguji hubungan umur, latar bahasa, lingkungan belajar, dan urutan pemerolehan. Subjek penelitiannya 120 anak berbahasa ibu Korea dan Spanyol. Mereka berumur 6 - 12 tahun. Untuk menguji pengaruh umur terhadap urutan pemerolehan subjek itu dipilah ke dalam 3 kelompok, yaitu kelompok 6 - 8 tahun, 9 - 11 tahun, dan $12-14$ tahun. Untuk menguji hubungan latar bahasa dengan urutan pemerolehan subjek dikelompokkan menjadi kelompok yang berbahasa ibu Korea dan yang berbahasa ibu Spanyol. Untuk menguji lingkungan belajar subjek dipilih menurut asal sekolah, yaitu sekolah yang mengajarkan bahasa Inggris secara khusus dan sekolah yang tidak mengajarkan bahasa Inggris secara khusus. Hasil analisis menunjukkan bahwa umur, B1, dan lingkungan belajar tidak memengaruhi urutan pemerolehan bahasa Inggris sebagai B2 (Saryono, 2010:100-101).

Kedua, Fathman (1975) mencoba meneliti aspek perubahan nilai dan urutan pemerolehan dalam kaitannya dengan umur. Sebanyak 200 orang yang sedang belajar bahasa Inggris sebagai B2 dan memiliki latar B1 berbeda dijadikan subjek penelitian. Mereka berumur 6 - 15 tahun. Dengan menggunakan tes produksi lisan, kemampuan mereka dalam memproduksi kalimat dan morfem dan pola kalimat diuji. Hasil analisis menunjukkan bahwa terdapat hubungan antara umur dan perubahan nilai dan tidak terdapat perbedaan dalam urutan pemerolehan antara pemelajar yang umur dan B1-nya berbeda (Saryono, 2010:101).

D’Anglejan dan Tucker (1975) meneliti pemerolehan struktur kompleks bahasa Inggris. Dua kelompok diteliti, yaitu kelompok pemula dan lanjut. Jumlah subjek 20 orang. Kelompok pemula rata-rata umurnya 19,7 tahun dan kelompok lanjut 24,55 tahun. Mereka rata-rata sudah dua belas tahun mengenyam sekolah formal. Dengan menggunakan lima macam tes struktur, urutan pemerolehan struktur kompleks bahasa Inggris diteliti. Hasil analisis menunjukkan bahwa terdapat pola 
perkembangan yang sama seperti temuan Chomsky (1969) pada anak-anak yang berumur 5 - 10 tahun. Pada kelompok pemula pemelajar cenderung menggunakan penafsiran semantic dalam menafsirkan kalimat-kalimat taksa. Tidak ditemukan bukti bahwa anak-anak berusaha menerjemahkan bahasa ibu ke dalam bahasa sasaran (Saryono, 2010:101).

Jika urutan pemerolehan B2 tidak dipengaruhi umur, latar B1, dan lingkungan belajar apakah urutan pemerolehan B2 juga tidak dipengaruhi oleh pengajaran formal? Beberapa kajian menunjukkan bahwa pengajaran secara formal tidak memengaruhi secara signifikan urutan pemerolehan B2. Pengajaran formal hanya mencerminkan penampilan atau pernyataan ini antara lain dikerjakan oleh Perkins dan Freeman, Felix, Linghbown.

\section{Struktur Sintaksis Bahasa Jawa dan Bahasa Indonesia}

Ada enam jenis kalimat (silah-silahing ukara) bahasa Jawa:

c. Kalimat langsung (ukara kandha)

\section{Contoh:}

- Bapak ngendika, "Sesuk aku menyang Solo".

- "Kowe kudu sing sregep sinau" dhuwuhe ibu.

b. Kalimat tak langsung (ukara crita)

Contoh:

- Tini takon, kena apa aku wingi ora mlebu sekolah.

- Ngendikane guru, yen sregep sinau mesthi pinter.

c. Kalimat aktif (ukara tindak/tanduk)

Contoh:

- Ibu mundhut jajan konggo tukang.

- Rudi ngundhuh jambu.

d. Kalimat pasif (ukara tanggap)

\section{Contoh:}

- Sarunge dikriti tikus.

- Jajane dirubung semut

e. Kalimat perintah (ukara pakon)

Contoh:

- Jupukna tasku ing dhuwur kursi kuwi.

- Jajane dirubung semut.

f. Kalimat permohonan (ukara panjaluk)

Contoh:

- Coba kowe meraneya dak kandhani.

- Tulung aku penekna blimbing kuwi.

\section{Penggunaan Bahasa}

(Rahimsyah \&Soedirman, tanpa tahun: 57-58)

Clark \& Clark (1977:373) mengemukakan bahwa anak-anak membangun struktur dan fungsi pada waktu yang bersamaan. Sebaiknya mereka belajar lebih banyak struktur, maka mereka memperoleh lebih banyak sarana untuk menyampaikan fungsi yang berbeda-beda. Dan sebaiknya mereka mempelajari banyak fungsi, maka mereka memperluas pemakaian tempat berbagai struktur diterapkan. Seperti halnya objek-objek yang mereka manipulasikan, maka bagi anakanak kecil "language is what language does". Dan bagi anak-anak masa sekolah yang lebih besar, bahasa juga merupakan masalah perbuatan: meyakinkan, menerapkan, 
menyenangkan orang, mencari informasi. Aspek fungsional bahasa ini sangat penting sehingga sudah sepantasnya dibicarakan secara khusus dan terperinci seperti yang dilakukan oleh Halliday (1973).

\section{Metode Peneltian}

\section{Pendekatan dan Jenis Penelitian}

Penelitian ini adalah jenis penelitian eksploratori dengan menggunakan pendekatan analitik-sintetik. Analitik-sintetik yang dimaksudkan dalam penelitian adalah melakukan pengkajian terhadap beberapa satuan dari bahasa kedua dengan memilah-milah satuan-satuan bahasa tersebut secara terpisah kemudian menyelidiki dan menarik kesimpulan dari satuan-satuan yang terpisah itu secara holistik (Selinger, 1989). Di antara satuan-satuan bahasa yang diteliti dalam penelitian ini adalah satuan sinktasis berupa kalimat dan klausa siswa siswa SD kelas V.

Dengan menggunakan pendekatan analitik-sintetik Analitik-sintetik maksudnya melakukan pengkajian terhadap beberapa satuan dari bahasa kedua dengan memilah-milah dan mencocokkan satuan-satuan bahasa tersebut secara terpisah kemudian menyelelidiki dan menarik kesimpulan dari satuan-satuan yang terpisah itu secara holistik (Selinger, 1989). Di antara satuan-satuan bahasa yang akan diteliti dalam penelitian ini adalah pengaruh sintaksis kalimat bahasa pertama terhadap penggunaan bahasa Indonesia siswa kelas V SD.

\section{Variabel Penelitian}

Penelitian ini meneliti tiga variabel, yaitu (1) struktur kalimat bahasa pertama Jawa dan (2) penggunaan bahasa Indonesia (kalimat bahasa Indonesia) yang terdiri atas (a) kemampuan analisis bahasa Indonesia, (b) kemampuan sintesis bahasa Indonesia dan (3) implikasi pemerolehan bahasa pertama dan pemerolehan bahasa Indonesia sebagai bahasa kedua terhadap pengajaran sintaksis.

\section{Data dan Sumber Data}

Data dalam penelitian ini adalah pengaruh struktur kalimat bahasa Jawa terhadap penggunaan bahasa Indonesia. Data yang dimaksud akan diperoleh/bersumber dari keseluruhan siswa kelas V SD Negeri 171 Purwosari di Kecamatan Tomoni Timur Kabupaten Luwu Timur tahun pelajaran 2019-2020 sebanyak 41 orang .

\section{Teknik Pengumpulan Data}

Teknik yang digunakan dalam penelitian ini:

a. Observasi berperan serta (Participant Observation): peneliti terlibat langsung dengan kegiatan sehari-hari siswa kelas V SD yang sedang diamati atau digunakan sebagai sumber data penelitian. Sambil melakukan pengamatan, peneliti ikut melakukan apa yang dikerjakan oleh sumber data, dan ikut merasakan suka dukanya. Dengan observasi partisipan ini, maka data yang diperoleh akan lebih lengkap, tajam, dan sampai mengetahui pada tingkat makna dari setiap perilaku yang nampak (Sugiyono, 2011:145). Semua percakapan siswa direkam dengan perekam digital sebagai data kualitatif. Kegiatan merekam ini dilakukan di kelas saat proses belajar berlangsung dan percakapan yang terjadi di luar kelas pada waktu istrahat.

b. Intervew/wawancara; dilakukan dengan kepala sekolah dan guru kelas V.

c. Kuesioner (Angket) yang digunakan meliputi: identitas responden, yang terdiri dari: (1) Nama siswa; (2) NIS; (3) Tempat tanggal lahir; (4) Nama Suku; (5) 
Agama ; (6) bahasa yang digunakan sehari-hari di rumah; (7) bahasa yang digunakan jika di luar rumah (ketika bermain dengan teman-temannya); (8) nama kedua orang tua;

d. Tes: (1) tes mengarang; (2) tes wacana B1 (Bahasa Daerah); dan (3) tes wacana B2 (Bahasa Indonesia)

\section{Teknik Analisis Data}

Dalam menganalisis data, peneliti menggunakan metode induktif. Maksudnya, peneliti tetap berpegang teguh pada informasi yang telah diperoleh dari lapangan, kemudian menganalisisnya berdasarkan teori dan kerangka pikir sebagaimana yang telah dikemukakan sebelumnya, yaitu teori yang mengacu kepada metode dan prosedur kerja teori pemerolehan bahasa.

Data yang telah diperoleh dari lapangan dianalisis melalui tiga tahapan.

a. Tahap pertama, mendeskripsikan struktur kalimat bahasa Jawa dan penggunaan bahasa Indonesia sebagai bahasa kedua, responden dalam hal analitik.

b. Tahap kedua, mendeskripsikan struktur kalimat bahasa Jawa dan penggunaan bahasa Indonesia sebagai bahasa kedua, responden dalam hal sintetik.

c. Tahap keempat, mempersentasekan penggunaan struktur kalimat bahasa Jawa dan penggunaan bahasa Indonesia sebagai bahasa kedua.

Selanjutnya, analisis dilakukan dengan menghitung dan mempersentasekan pengaruh struktur kalimat bahasa Jawa terhadap penggunaan bahasa Indonesia sebagai bahasa kedua.

\section{Hasil Penelitian}

\section{Struktur kalimat bahasa Jawa dan penggunaan bahasa Indonesia sebagai kedua}

Kondisi penggunaan bahasa Indonesia terutama sasaran penelitian mengenai struktur kalimat responden, baik secara analitik maupun sintetik menunjukkan adanya pengaruh dari bahasa pertama (Jawa). Pengaruh tersebut dapat dilihat melalui realisasinya dalam kehidupan sehari-hari. Apakah realisasinya terjadi di lingkungan keluarga, masyarakat, maupun lingkungan sekolah. Hal itu dapat ditunjukkan beberapa data yang diperoleh melalui penelitian. Adapun data-data tersebut adalah sebagai berikut:

\section{a. Penggunaan kalimat bahasa Jawa secara analitik yang berbahasa Indonesia}

Penggunaan kalimat yang dimaksud dalam penelitian ini adalah tulisan dalam karangan responden yang terdiri atas minimal dua atau tiga unsur fungsi dalam kalimat yaitu subjek, predikat, dan objek. Penggunaan kalimat oleh responden mewakili beberapa pola struktur kalimat dan berbagai variasi kalimat. Penggunaan kalimat yang tampak dalam tulisan responden antara lain meliputi kalimat tunggal, kalimat majemuk, kalimat tanya, kalimat penyangkalan, kalimat pasif, dan kalimat aktif. Berikut ini dijelaskan variasi-variasi kalimat dan pola strukturnya yang ditemukan dalam karangan responden.

1) Kalimat deklaratif

Bersama ayah dan ibu dengan tetangga-tetangga ikut bersama keluargaku

Subjek - predikat dengan mengendarai mobil (001)

keterangan $(\mathrm{S}-\mathrm{P}-\mathrm{K})$ 
$\underline{\text { Aku dan ibu pergi ke rumah kakek dan nenek untuk merayakan hari raya idul }}$ Subjek - predikat - objek (S - P - O)

fitri (002)

Pada malam hari aku dan teman-temanku bahas Ilhahi di poskamling (003)

Keterangan - subjek - predikat - keterangan (K - S - P - K)

Aku pergi ke rumah saudaraku bersama kedua orang tua (004)

Subjek - predikat - objek (S - P - O)

Saya dan seluruh anggota pramuka mengumpulkan kayu akan dinyalahkan

Subjek - predikat - objek -

pada malam minggu (005)

keterangan ( $\mathrm{S}-\mathrm{P}-\mathrm{O}-\mathrm{K})$

Saya sungguh senang jalan-jalan ke rumah keluargaku (006)

Subjek - predikat - objek (S - P - O)

Aku di rumah main bola (007)

Subjek - keterangan - predikat - objek (S - K - P - O)

Saya dapat meminta maaf kepada orang tuaku (008)

Subjek - predikat - objek (S - P - O)

Pada hari raya idul fitri aku dan keluarga bersiap berangkat ke mesjid (009)

Keterangan - subjek - predikat - keterangan (K - S - P - K)

Saya mengajak teman-teman untuk pergi ke rumah ibu guru (010)

Subjek - predikat - keterangan (S - P - K)

Aku dan keluargaku bersama-sama shalat Id di pelabuhan Makassar (011)

Subjek - predikat - keterangan ( $\mathrm{S}$ - P - K)

Aku tiba-tiba takut memendang perasaan aku terkena api (012)

Subjek - predikat - objek (S - P - O)

Aku pulang ke rumah dan pergi jalan-jalan bersama keluargaku (013)

Subjek - predikat - objek (S - P - O)

Aku dan teman-temanku menjenguk guruku yang sedang dirawat di rumah

Subjek - predikat - objek - keterangan (S - P - O - K)

sakit (014)

Kami berziarah ke rumah saudara-saudara kami (015)

Subjek - predikat - keterangan - objek (S - P - K - O)

Aku suka banget hari raya itu (016)

Subjek - predikat - objek (S - P - O)

Sabil melihat indahnya pemandangan jalan (017)

Subjek - predikat - objek (S - P - O)

Kami duduk-duduk sebentar dengan paman (018)

Subjek - predikat - objek (S - P - O)

Tahun baru itu sangat menyenangkan (019)

Objek - predikat (O - P)

Saya makan di rumah (020)

Subjek - predikat - keterangan (S - P - K)

Saya langsung melihat orang balapan motor (021)

Subjek - predikat - objek (S - P - O)

Saya berangkat pukul 10-30 (022)

Subjek - predikat - keterangan (S - P - K) 
Aku mau singgah ke Masamba nek (023)

Subjek - predikat - keterangan ( $\mathrm{S}$ - P - K)

Berdasarkan korpus dan analisisnya terlihat beberapa pola struktur kalimat yakni S - P - K; S - P - O; S - P - O - K; K - S - P - K; S - K - P - O; S - P - K - O; dan O $P$. Hal itu menunjukkan bahwa anak sekolah dasar yang berada pada rentang umur 10 - 11 tahun sudah mampu menuliskan pola-pola kalimat bahasa Indonesia yang bervariasi.

2) Kalimat tanya

Kita menungu berapa menit? (001)

Kamu mau apa? (010)

Kapan kita tahun baru? (019)

Kapan kamu pulang ke Mangkutana? (023)

Kenapa kami tidak tinggal di rumah nenek dan sekolah di sini? (023)

Contoh-contoh kalimat tersebut menunjukkan bahwa selain mampu menggunakan kalimat tanya dengan kata-kata tanya seperti berapa, apa, kapan, kenapa (mengapa), responden juga dapat menggunakan kalimat tanya dengan menggunakan tanda baca tanya.

3) Kalimat penyangkalan

Supaya kita tidak berdosa dengan orang lain (006)

Aku tidak jalan-jalan karena sudah hampir semua saya kunjungi (007)

Saat aku tidak melihat makam nenek (009)

Ayo kita pergi sekarang ke sana sekarang tapi kesal kami tidak mau (010)

Tidak tahu kapan kita tahun baru (019)

Tidak kami rasa hari semakin siang dan kami pun segera pulang (022)

Kita pergi ke agro tetapi tidak jadi karena sekalian shalat Jumat (023)

Aku tidak mau nek (023)

Nek aku mau tinggal di sini tetapi aku tidak boleh (023)

Aku menangis karena tidak boleh tinggal di sini (023)

Jadi aku boleh tinggal di sini tetapi tidak sekolah di sini (023)

Contoh-contoh kalimat tersebut menunjukkan bahwa responden selain mampu menggunakan kalimat penyangkalan dengan kata penyangkalan seperti tidak. Meskipun penggunaan kata penyangkalan hanya ditemukan satu saja yaitu kata tidak. 4) Kalimat majemuk

Setelah sudah bersiap-siap kita semua akan berangkat dan kita akan menaiki mobil dan mobilnya terbuka dan kita berangkat dan kita menunggu berapa menit (001)

Kalimat tersebut terjadi pelesapan subjek (kita) pada awal kalimat dan penggunaan kata kita yang berlebihan.

Aku pulang dan bertemu teman-temanku lagi (002)

Pada siang hari aku dan omku membelikan bola di pasar untuk nanti malam tahun baru (003)

Bersama teman-temanku dan bersama kakak-kakakku bunyikan petasan lagi pada waktu itu aku sangat senang diajak (003) (004)

Aku pergi ke rumah tetanggaku bersama teman-teman dan aku minta terus

Kalimat tersebut terjadi pelesapan subjek (kita) dan dua kali menggunakan kata kita, sebaiknya kata hanya satu kali digunakan yaitu pada awal induk kalimat. 
Pada suatu hari saya dan teman-teman mengadakan perkemahan yang akan dilaksanakan pada hari sabtu minggu saya disuruh membawa bambu, terpal, kompor, korek api lalu saya dan teman-teman mendirikan tenda (005)

Kalimat ini terjadi pelesapan subjek (saya), baik pada induk kalimat maupun pada anak kalimatnya.

Saya sangat senang jalan-jalan ke rumah keluargaku dan rumah nenekku dan nenekku merasa senang karena cucunya datang dan keluarganya pun senang karena idul fitri (006)

Aku bersama-sama temanku saya manaiki sepeda teman-temanku banyak dan juga kita langsung pamit ke rumah orang lain (007)

Kalimat ini terjadi penggunaan subjek (aku, saya, dan kata ganti -ku) yang tumpang-tindih, sebaiknya cukup hanya konsisten menggunakan subjek aku atau saya.

Saya pergi di makam nenekku yang laki-laki saya di sana membersihkan makam nenekku lalu saya berdoa dan menyiramkan bunga di makam nenekku (008)

Kalimat di atas, ditunjukkan terjadinya pelesapan subjek (saya), baik pada induk kalimat maupun pada anak kalimatnya.

Akupun bersalam-salaman dengan saudara dan sepupuku dan aku ke rumah kakek, nenek akupun meminta ampun atas apa yang telah aku perbuat (009)

Kalimat di atas, ditunjukkan pelesapan subjek (aku), baik pada induk kalimat maupun anak kalimatnya.

Setelah aku lama beristrahat aku langsung berangkat dengan mamaku pergi ke kuburan alm.bapak kandungku dan kuburan nenekku dan setelah aku sampai di kuburan aku langsung membersihkan kuburan bapakku (011)

Kalimat di atas, ditunjukkan terjadinya pelesapan subjek (aku), baik pada induk kalimat maupun pada anak kalimat juga menunjukkan kalimat tersebut tidak efektif dan kurang sesuai pola kalimat bahasa Indonesia yang baku.

Aku pulang ke rumah dan pergi jalan-jalan bersama keluargaku (013)

Pada pagi hari aku ingin pergi ke mesjid untuk melaksanakan salat idul fitri aku dan ayah sampai di masjid dan mengambil air wudhu setelah berwudhu aku melaksanakan salatnya (014)

Kalimat di atas, ditunjukkan terjadinya pelesapan subjek (aku), baik pada induk kalimat maupun pada anak kalimat.

Kami pulang dan beristrahat sebentar setelah ibu kami berziarah ke tempat saudara-saudara dekat dan ke tempat tetangga-tetangga juga yang dekat dengan rumah kami (015)

Kalimat di atas, ditunjukkan terjadinya pelesapan subjek (kami), baik pada induk kalimat maupun pada anak kalimat.

Aku ke rumah saudaraku bersama ayah, ibu dan aku jalan-jalan bersama teman-temanku dan aku ke sana menaiki sepeda (016)

Kalimat tersebut, ditunjukkan terjadinya pelesapan subjek (aku), baik pada induk kalimat maupun pada anak kalimat.

Saya bakar-bakar ikan itu saya main bola sama teman-teman saya di lapangan kami minum es kelapa muda (020)

Kalimat tersebut, ditunjukkan terjadinya pelesapan subjek (saya), baik pada induk kalimat maupun pada anak kalimat. 
Suatu hari saya, ibu, ayah dan adik pergi rekreasi ke pantai balo-balo pada hari minggu 20-12-2015 saya berangkat mengendarai motor (022)

Kalimat di atas, ditunjukkan terjadinya pelesapan subjek (saya), baik pada induk kalimat maupun pada anak kalimat sehingga kalimat tersebut menjadi rancu.

Waktu itu aku pergi ke agro bersama ayah dan ibu aku pergi pada libur panjang aku pergi ke rumah nenek, dan kakek (023)

Kalimat di atas, ditunjukkan terjadinya pelesapan subjek (aku), baik pada induk kalimat maupun pada anak kalimat.

5) Kalimat pasif

Bersama kakak-kakakku bunyikan petasan lagi (003)

Saya disuruh membawa bambu, terpal, kompor, korek api (005)

Saya di sana diberi makanan (008)

Aku disuruh sarapan oleh ibuku (014)

Setelah lama kami di perjalanan tibalah kami di rumah saya (021)

Ketika kami sedang ada di jalan kami melihat ada orang (022)

Lalu kami di sana bermain lompat karet (023)

Tampak pada data penelitian bahwa selain pemakaian kalimat berita, responden juga sudah mampu menghasilkan kalimat-kalimat transformasi ke dalam bentuk kalimat tanya dan kalimat penyangkalan dari kalimat tunggal ke kalimat majemuk; transformasi dari kalimat aktif ke kalimat pasif.

6) Kalimat aktif

Aku dan teman-temanku mandi di pantai (001)

Dia mengajaku pergi ke rumahnya untuk merayakan hari raya idul fitri (002)

Teman-temanku memotong-motong ikan yang sudah aku beli (003)

Aku pergi ke rumah temanku dan aku bicara dengan sopan dan baik (004)

Saya dan teman-teman mendirikan tenda (005)

Kita menuju ke mesjid (006)

Saya bertemu teman-teman kita (007)

Saya pergi di rumah tetangga-tetanggaku (008)

Aku dan keluarga bersiap berangkat ke mesjid untuk shalat Id (009)

Saya mengajak teman-teman (010)

Aku langsung berangkat dengan mamaku (011)

Aku senang tahun baru (012)

Kami berpamitan ingin pergi ke rumah ibu dan bapak guru (013)

Kita mengumpulkan uang bersama untuk membeli buah-buahan (014)

Aku dan teman-temanku pamit untuk pulang ke rumah masing-masing (015)

Aku shalat di mesjid (016)

Paman pergi ke warung untuk membeli minuman dan makanan (017)

Kami melihat orang balapan di balo-balo (018)

Kami bakar ikan di rumah (020)

Saya dan keluarga jalan-jalan ke pantai (021)

Saya bersama adik berenang bersama (022)

Aku pergi pada libur panjang di rumah nenek (023)

Tampak pada data penelitian menunjukkan bahwa frekuensi responden lebih sering menggunakan kalimat aktif dibanding dengan penggunaan jenis kalimat lain di dalam karangannya. 


\section{b. Persentase Penggunaan Struktur Kalimat Bahasa Jawa dan Penggunaan Bahasa Indonesia sebagai Bahasa Kedua}

Pengaruh struktur kalimat bahasa Jawa terhadap penggunaan kemampuan analitik (analisis) bahasa Indonesia sebagai bahasa kedua, peneliti menghitung persentase penggunaan pola atau struktur kalimat bahasa Jawa kemudian menghitung persentase penggunaan pola atau struktur kalimat bahasa Jawa yang sesuai dan yang tidak sesuai dengan struktur kalimat bahasa kedua yaitu struktur kalimat bahasa Indonesia.

Pola atau struktur kalimat bahasa Jawa yang ditemukan dalam karangan siswa yang sesuai dengan pola kalimat bahasa kedua (bahasa Indonesia), ada tiga pola atau struktur kalimat yaitu: (1) subjek - predikat - keterangan (S - P - K); (2) subjek predikat - objek (S - P - O); dan (3) subjek - predikat - objek - keterangan ( $-\mathrm{P}$ - 0 - K). Dari 23 karangan siswa yang diteliti dan dianalisis ditemukan 19 (83 persen) karangan siswa yang menggunakan pola kalimat bahasa Indonesia berpola subjek predikat - objek ( $\mathrm{S}$ - P - 0); 15 (65 persen) karangan siswa yang menggunakan pola kalimat bahasa Indonesia berpola subjek - predikat - keterangan ( $\mathrm{S}-\mathrm{P}-\mathrm{K})$; dan 9 (39 persen) karangan siswa yang menggunakan pola kalimat bahasa Indonesia berpola subjek - predikat - objek - keterangan ( $-\mathrm{P}-\mathrm{O}-\mathrm{K})$.

Pola atau struktur kalimat bahasa Jawa yang ditemukan dalam karangan siswa yang tidak sesuai dengan pola kalimat bahasa kedua (bahasa Indonesia), ada lima pola atau struktur kalimat yaitu: (1) objek - predikat (O - P); (2) keterangan - subjek - predikat - keterangan (K-S - P - K); (3) subjek - keterangan - predikat - objek (4) ( $\mathrm{S}-\mathrm{K}-\mathrm{P}-\mathrm{O}$ ); dan (5) subjek - predikat - keterangan - objek ( $\mathrm{S}-\mathrm{P}-\mathrm{K}-\mathrm{O}$ ). Dari 23 karangan siswa yang diteliti dan dianalisis ditemukan 5 (22 persen) karangan siswa menggunakan pola kalimat yang berpola objek - predikat (O - P); 7 (30.4 persen) karangan siswa menggunakan pola kalimat keterangan - subjek - predikat keterangan ( $\mathrm{K}-\mathrm{S}-\mathrm{P}-\mathrm{K}$ ); 9 (39.1 persen) karangan siswa menggunakan pola kalimat yang berpola subjek - keterangan - predikat - objek ( $\mathrm{S}-\mathrm{K}$ - P - 0); dan 8 (35 persen) karangan siswa menggunakan pola kalimat yang berpola subjek - predikat keterangan - objek ( $\mathrm{S}-\mathrm{P}-\mathrm{K}-\mathrm{O}$ ).

Penggunaan pola atau struktur kalimat bahasa pertama (Jawa) yang tidak sesuai struktur kalimat bahasa kedua (bahasa Indonesia), seperti: (1) pola kalimat objek-predikat (O-P); (2) pola kalimat keterangan-subjek-predikat-keterangan (K-SP-K); (3) pola kalimat subjek-keterangan-predikat-objek (S-K-P-O); dan (4) pola kalimat subjek-predikat-keterangan-objek (S-P-K-O).

\section{1) Penggunaan jenis kalimat tanya responden dalam karangannya}

Pada jenis kalimat tanya yang digunakan responden dalam karangannya semua responden mampu menggunakan kata-kata tanya dalam kalimat. Dari 22 karangan yang diteliti dan dianalisis tidak ditemukan satupun kalimat yang menggunakan kata-kata tanya. Tetapi bukan berarti responden sama sekali tidak pernah menggunakan kata-kata tanya dalam kalimat. Ketika responden melakukan interaksi secara lisan, baik dalam kelas maupun di luar kelas tetap mereka menggunakan kata-kata tanya dalam kalimat jika situasi komunikasi menuntutnya untuk menggunakan kata tanya dalam kalimat. Hal tersebut peneliti menyaksikan melalui pengamatan ketika mengadakan penelitian. 
Contoh kata tanya yang digunakan responden seperti kata berapa, apa, kapan, kenapa (mengapa). Khusus kata kenapa dalam tata bahasa baku bahasa Indonesia termasuk kata tanya tidak baku, yang baku mengapa.

\section{2) Penggunaan jenis kalimat penyangkalan responden dalam karangannya}

Penggunaan kata penyangkalan dalam jenis kalimat penyangkalan dapat berupa kata tidak. Kata tidak ini telah digunakan responden dalam karangannya telah sesuai buku Tata Bahasa Baku Bahasa Indonesia edisi ketiga tahun 2003 hal. 378 dinyatakan bahwa kalimat penyangkalan (pengingkaran kalimat) dilakukan dengan menambahkan kata ingkar yang sesuai di awal frasa predikatnya. Kata ingkar tidak ditempatkan di awal predikat yang tidak mengandung bentuk sudah atau telah pada kalimat berpredikat: (a) verbal, jenis deklaratif, dan interogatif; (b) adjektival, jenis deklaratif, interogatif, dan eksklamatif; dan (c) numeral taktentu, jenis deklaratif dan interogatif.

Penggunaan kata ingkar tidak sebagian besar responden, telah menggunakan kata ingkar tidak dalam kalimat sesuai dengan teori yang diuraikan dalam buku Tata Bahasa Baku Bahasa Indonesia.

\section{3) Penggunaan jenis kalimat majemuk responden dalam karangannya}

Penggunaan jenis kalimat majemuk, baik majemuk setara maupun majemuk bertingkat pada karangan responden ditandai dengan berfungsinya kata sambung atau konjungsi dalam kalimat majemuk tersebut. Dalam Tata Bahasa Baku Bahasa Indonesia (2003:398-414) dijelaskan bahwa klausa yang terdapat dalam kalimat majemuk setara dihubungkan oleh koordinator seperti dan, serta, lalu, kemudian, tetapi, padahal, sedangkan, baik--- maupun..., tidak...tetapi..., dan bukan...melainkan...

Semantara pada kalimat majemuk bertingkat dihubungkan oleh hubungan antara klausa subordinatif dan klausa utama banyak ditentukan oleh jenis dan fungsi klausa subordinatif. Berikut adalah beberapa macam hubungan semantis yang ada antara klausa subordinatif dan klausa utama: (1) hubungan waktu meliputi waktu batas permulaan: sejak, sedari, waktu bersamaan: sewaktu, ketika, seraya, serta, sambil, sementara, selagi, tatkala, selama, waktu berurutan: sebelum, setelah, sesudah, seusai, begitu, sehabis, waktu batas akhir: sampai, hingga (2) hubungan syarat seperti jika (lau), kalau, asal(kan) di samping itu, subordinator kalau, (apa) bila, dan bilamana juga dipakai jika syarat itu bertalian dangan waktu, (3) hubungan pengandaian: seandainya, andaikata, andaikan, dan sekiranya, (4) hubungan tujuan: agar, supaya, untuk, dan biar, (5) hubungan konsesif: walau(pun), meski(pun), sekalipun, biar(pun), kendati(pun), sungguh(pun), dan biarpun. (6) hubungan pembandingan: seperti, bagaikan, laksana, ibarat, sebagaimana, daripada, dan alihalih, (7) hubungan sebab atau alasan (penyebaban): sebab, karena, akibat, dan oleh karena, (8) hubungan hasil atau akibat: sehingga, sampai (-sampai), dan maka, (9) hubungan cara: dengan dan tanpa, (10) hubungan alat: dengan dan tanpa, (11) hubungan komplementasi: bahwa, (12) hubungan atribut : (a) restriktif dan (b) takrestriktif, dan (13) hubungan perbandingan: (a) hubungan ekuatif: sama...dengan, (b) hubungan komparatif: lebih/kurang...dari(pada), (c) hubungan optatif: semoga atau moga-moga dan mudah-mudahan.

\section{4) Penggunaan kalimat pasif dan aktif responden dalam karangannya}

Kalimat aktif yang dapat diubah menjadi kalimat pasif adalah kalimat aktif yang fungsi predikatnya diisi oleh verba transitif, yaitu verba yang memiliki komponen makna (+ tindakan) dan (+ sasaran) atau (+ hasil). Proses pembentukan 
kalimat pasif dari sebuah kalimat aktif dilakukan dengan langkah: (1) memindahkan objek kalimat aktif menjadi subjek dalam kalimat pasif, (2) memindahkan subjek kalimat aktif menjadi objek kalimat pasif, mengubah bentuk verba dari dari berprefiks me- menjadi verba berprefiks di-. Dan (3) menempatkan preposisi oleh sebagai penanda pelaku secara opsional di antara predikat dan objek pelaku (Chaer, 2009:201-202).

Sesuai data penelitian yang diteliti dan dianalisis kemudian dikaitkan dengan di atas maka ditemukan bahwa penggunaan kalimat pasif dan aktif responden pada karangan yang berbahasa pertama Jawa kurang sesuai dengan kaidah bahasa kedua (bahasa Indonesia) yaitu proses perubahan kalimat aktif menjadi kalimat pasif ditandai dengan mengubah bentuk verba dari berprefiks me- menjadi verba berprefiks di-. Hal ini dapat ditemukan pada kalimat yang ditulis responden.

\section{Implikasi pemerolehan bahasa pertama dan pemerolehan bahasa Indonesia sebagai bahasa kedua terhadap pengajaran sintaksis}

Sesuai data penelitian yang diteliti melalui instrumen berupa angket yang diisi oleh responden dan dikaitkan dengan hasil karangannya, maka dapat dikemukakan bahwa pemerolehan bahasa pertama berpengaruh terhadap penggunaan bahasa Indonesia sebagai bahasa kedua, baik dalam kehidupan di lingkungan masyarakat maupun di lingkungan sekolah. Ada beberapa kenyataan yang perlu dikemukakan juga di sini yaitu bahwa hampir pada umumnya responden jika berkomunikasi secara lisan dengan anggota keluarga di rumah menggunakan bahasa pertama, akan tetapi sebagian kecil juga terjadi campur kode, alih kode, bahkan interferensi pada responden saat berkomunikasi dengan anggota keluarganya terutama jika berkomunikasi dengan ayah, ibu, dan nenek mereka. Karena pengaruh dari komunikasi terjadi di lingkungan keluarga yang menjadi kebiasaan yang tidak sadari sehingga ketika ke sekolah kebiasaan tersebut terbawa-bawa sampai ke dalam kelas dan kebiasaan tersebut aplikasinya terlihat ketika responden berinteraksi sesama responden lainnya, baik dalam kelas maupun di luar kelas. Apakah komunikasi itu terjadi secara lisan maupun tulisan? Kaidah bahasa pertama sehari-hari mereka gunakan berpengaruh pada kaidah bahasa kedua (bahasa Indonesia) sebaliknya kadangkala kaidah bahasa kedua berpengaruh pada kaidah bahasa pertama, baik bentuk frasa, klausa, dan kalimat yang dihasilkan dan digunakan dalam bentuk bahasa lisan maupun tulisan. Yang paling menonjol teramati adalah ketika berkomunikasi dalam bentuk lisan. Kaidah bahasa mereka berupa campur kode, alih kode bahkan berupa interferensi.

Dari kenyataan tersebut tidak dapat dipungkiri karena di Indonesia ini (terutama di wilayah Tomoni Timur) merupakan wilayah transmigrasi yang menunjukkan sebagai wilayah Indonesia mini. Otomatis ketika masyarakat berkomunikasi dengan suku dan bahasa yang berbeda hanya dipersatukan oleh bahasa Indonesia sebagai bahasa kedua. Hal seperti itu terjadi pada lingkungan masyarakat. Lain halnya jika di lingkungan keluarga bahasa pertamalah yang sangat berperan penting. Karena komunikasi yang terjadi di lingkungan keluarga itu, rasa, nilai, dan keakraban terjadi antaranggota keluarga itu dapat dipersatukan melalui bahasa pertama, terutama komunikasi yang terjadi antara ayah -ibu, ayah-nenek, ibunenek. Namun, tidak bisa juga dipungkiri bahwa kadangkala komunikasi terjadi dengan ayah-anak, ibu-anak, nenek-cucu, kakak-adik, dan adik-kakak terjadi campur kode dan alih kode bahkan dapat juga terjadi dengan menggunakan bahasa kedua 
(bahasa Indonesia) terutama komunikasi antara kakak-adik. Kenyataan seperti itulah yang menjadi budaya bagi masyarakat yang hidup di wilayah transmigrasi.

Di wilayah Tomoni Timur ini masyarakat hidup secara berkelompok sesuai suku, budaya, dan bahasa mereka. Hal itulah yang menyebabkan sehingga pemerintah pusat dan daerah mengambil kebijakan mendirikan sekolah terutama sekolah dasar disesuaikan dengan kelompok etnis. Bahkan hampir pada umumnya tenaga edukatif mulai dari kepala sekolah sampai guru-guru yang mengajar disesuaikan juga dengan kelompok etnis.

\section{Simpulan}

Berdasarkan hasil analisis data dalam penelitian ini, disimpulkan beberapa hal sebagai berikut:

1. Pola atau struktur kalimat bahasa Jawa yang sesuai dengan struktur kalimat bahasa Indonesia yang digunakan responden dalam karangannya terdiri atas: (1) subjek-predikat (S-P), (2) subjek-predikat-objek (S-P-O) semua responden menggunakan dalam karangannya, (3) subjek-predikat-keterangan (S-P-K) semua responden menggunakan dalam karangannya, dan (4) subjek-predikat-objekketerangan (S-P-O-K) semua responden menggunakan dalam karangannya.

2. Penggunaan pola atau struktur kalimat bahasa Jawa yang tidak sesuai struktur kalimat bahasa Indonesia yang digunakan responden dalam karangannya terdiri atas: (1) pola kalimat objek-predikat (O-P), (2) pola kalimat keterangan-subjekpredikat-keterangan (K-S-P-K), (3) pola kalimat subjek-keterangan-predikat-objek (S-K-P-O), (4) pola kalimat subjek-predikat-keterangan-objek (S-P-K-O). Jenis kalimat yang digunakan responden dalam karangannya adalah: (1) kalimat tanya, (2) kalimat penyangkalan semua responden menggunakan kata ingkar tidak dalam karangannya, (3) Sebagian besar responden menggunakan kalimat majemuk dalam karangan kurang sesuai dengan kaidah bahasa kedua (bahasa Indonesia), dan (4) kalimat pasif dan aktif dalam karangannya kurang sesuai dengan kaidah bahasa kedua (bahasa Indonesia).

3. Implikasi pemerolehan bahasa pertama dan pemerolehan bahasa Indonesia sebagai bahasa kedua terhadap pengajaran sintaksis (pengajaran bahasa Indonesia) di sekolah terjadi kesenjangan di antara bahasa Jawa dan bahasa Indonesia artinya bahwa pengajaran bahasa Indonesia di sekolah dipengaruhi oleh penggunaan bahasa pertama responden, baik dari segi kaidah bahasa pertama maupun dari segi aksen bahasa pertama.

\section{Daftar Pustaka}

Alwi, Hasan. dkk. 2003. Tata Bahasa Baku Bahasa Indonesia. Edisi Ketiga. Jakarta: Balai Pustaka.

Arifin, Syamsul, dkk. 1999. Kalimat Pasif dalam Bahasa Jawa. Jakarta: Depdikbud.

Brown, R. and Bellugi,U. 1987. Three Processes in the Chid's Acquisation Syntax. Dalam Bar-Adon and Leopold (eds). Child Language: A Book of Readings.

Chaer, Abdul \& Leonie Agustina. 2004. Sosiolinguistik Perkenalan Awal. Jakarta: Rineka Cipta.

Chaer, Abdul. 2007. Psikolinguistik Kajian Teoretik. Jakarta: Rineka Cipta.

Chaer, Abdul. 2009. Sintaksis Bahasa Indonesia (Pendekatan Proses). Jakarta: Rineka Cipta. 
Chomsky, N. 1969. The Acquisition of Syntax in Children from 5 to 10. Cambridge Massachusetts: The MIT Press.

Chomsky, N. 1965. Aspecis of the Theory of Syntax. Massachusetts: The MIT Press.

Cook, V. 1988. Chomsky's Universal Grammar: An Introduction. New York: Basil Blackwell Inc.

Clark, Herbert and Eve V.Clark. 1977. Psychology and Language: An Introduction to Psycholinguistics. New York: Harcourt Broce Javanovich, Inc.

D’Anaglejan, Alison dan G.Richard Tucher. 1975. "The Acquisition of Complex English Structures by Adult Learners" dalam Language Learners. No. 2, 35. Desember 1975, hlm. 181-196.

Departemen Tenaga Kerja dan Transmigrasi. 2009. Undang-Undang Ketransmigrasian. Jakarta: Depnaker.

Dulay, Heidi dan Burt, Marina. 1975. Errors and strategies in child second language acquisition. Tesol Quarterly, 8:120 -136.

Ellis, Rod. 1985. Classroom Second Language Development. Oxford: Oxford University Press.

Felis, S. 1981. Second Language Acquisition. Tubigen: Gunther Narr.

Fodor, J.A. and Katz, J.J. 1965. The Structure of Language, Readings in the Philosophy of Language. Englewood Cliffs, New Jersey: Prentice-Hall, Inc.

Fishman, Joshua. 1973. Language and Nationalism. Massachusetts: Newburry House Publisher Inc.

Harsia. 2018. Pengaruh Struktur Sintaksis Bahasa Pertama terhadap Pemakaian Bahasa Indonesia Siswa Kelas V SD Kecamatan Tomoni Timur Kabupaten Luwu Timur. Makassar: Pascasarjana Universitas Negeri Makassar. (Disertasi, tidak diterbitkan).

Haryono, Inny C. 1990. "Kelompok Dwibahasawan Indonesia - Cina Putunghua di Pancoran, Jakarta Barat" dalam Muhadjir dan Basuki Suhardi (Ed).

Hockett, Charles F. 1958. A Course in Modern Linguistics. New York: Mac Millan Publising Co, Inc.

Hyams, N.M. 1986. Language Acquisition and the Theory of Parameters. Dordreeht D. Reidel Publishing Company.

Krashen, Stephen D. 1985. Principle and Practise in Second Language Acquisition. New York: Pergamon Press.

Kridalaksana, Harimurti. 2008. Kamus Linguistik; Edisi Keempat. Jakarta: PT. Gramedia Pustaka Utama.

Lightbown, M.P. \& Spada, N. 1993. How Language are Learned. Oxford: Oxford University Press.

Mackey, W.P. 1970. "The Description of Bilingualism” dalam J.A. Fishman (Ed).

Mar'at, Samsunuwiyati. 2011. Psikolinguistik Suatu Pengantar. Bandung: PT. Refika Aditama.

Moleong, Lexy J. 2010. Metodologi Penelitian Kualitatif. Bandung: PT. Remaja Rosdakarya.

Mulyadi. 1987. Urutan Pemerolehan Kalimat Bahasa Indonesia Tulis Siswa SMP yang Berbahasa Ibu Bahasa Jawa. Malang: Fakultas Pascasarjana IKIP Malang. (Tesis, tidak diterbitkan).

Nurcholis, Hanif \& Mafrukhi. 2007. Sasebi; Saya Senang Berbahasa Indonesia untuk Sekolah Dasar Kelas V; KTSP 2006. Jakarta: Erlangga. 
Poedjosoedarmo, Soepomo. 1994. Kode dan Alih Kode. Yogyakarta: Balai Penelitian Bahasa.

Pinker, S. 1984. Language Learnability and Language Development. Cambridge, Massachusetts: Harvard University Press.

Rahimsyah \& Soedirman, tanpa tahun. Pinter Basa Jawa.Surabaya: Palapa.

Saryono, Djoko. 2010. Pemerolehan Bahasa Teori dan Serpih Kajian. Malang: Nasa Media.

Selinger, Herbert W. \& Elana Shohamy. 1989. Second Language Research Methods. New York: Oxford University Press.

Soewito. 1983. Sosiolinguistik: Teori dan Problema. Surakarta: Kenary Off set.

Sugono, Dendy, dkk. 2008. Kamus Besar Bahasa Indonesia; Edisi Keempat. PT. Gramedia Pustaka Utama.

Sugiyono. 2011. Metode Penelitian Kuantitatif Kualitatif dan R \& D. Bandung: Alfabeta. Sumarsono.1997. "Bahasa Daerah sebagai Muatan Lokal:Ihwal Materi dan Metode" dalam Jurnal Linguistik Indonesia. Jakarta: MLI.

Widada. 1994. "Bahasa Jawa Etnis Bali: Telaah Struktur dan Fungsinya”. dalam Jurnal Linguistik Indonesia. Jakarta: MLI. 